\title{
An Assessment of the Distribution of Heavy Metals in the Riverine Sediments of Kortalaiyar River in Tamilnadu, India
}

\author{
N Bhuvana ${ }^{1}$, B Jeyaprabha ${ }^{2}$, M Amutha ${ }^{3}$, P Prakash $^{4, *}$ \\ ${ }^{I}$ Department of Chemistry, Jeppiaar Institute of Technology, Chennai, Tamilnadu, India \\ ${ }^{2}$ Department of Civil Engineering, Fathima Michael College of Engineering and Technology, Madurai, India. \\ ${ }^{3}$ Department of Chemistry, VVV College for women, Virudhunagar, India. \\ 4, "Department of Chemistry, Thiagarajar College, Madurai, Tamilnadu, India.
}

\begin{abstract}
The pollution of the natural environment is a universal problem. The heavy metals released in the environment as the result of human activities, atmospheric depositions and erosions would finally enter in to the aqua systems. Since, heavy metals are toxic, stable in the environment and are highly potential to combine with the nutritive continuum. Thus, they are considered as one of the most significant pollutant in aqua systems. In the present study, the distribution of heavy metals in the sediments of the Kortalaiyar river in the Chennai region from the Poondi Lake is evaluated. The Kortalaiyar River forms a main source of agriculture and domestic purpose along its flow area. It is assessed that this river is contaminated with the heavy metals like $\mathrm{Cr}$, $\mathrm{Ni}, \mathrm{Cu}, \mathrm{Mn}, \mathrm{Zn}, \mathrm{Ti}, \mathrm{Co}, \mathrm{Pb}$ and $\mathrm{Cd}$.Though the concentrations of the $\mathrm{Co}, \mathrm{Pb}$ and $\mathrm{Cd}$ are below detectable levels in few locations, the other heavy metals exhibit their existence in significant levels. The distribution of these heavy metals in the Pre-Monsoon and the Post-Monsoon seasons have been studied and it has been analyzed using the dendrograms of the cluster analysis.
\end{abstract}

Key Words: Kortalaiyar River, Sediments, Ennore Creek, Heavy Metals, Dendrograms, Cluster Analysis.

\section{Introduction}

It is well known that significant amount of contaminants are introduced into rivers, estuaries and coastal regions due to increase in the industrial activities, economic development and urbanization in the metropolitan cities all over the world in recent years . Heavy metals are the serious pollutants among the various aquatic ecosystems. It is due to their environmental persistence, toxicity and ability to be incorporated into food chains $[1,2]$.

Numerous studies have revealed that the riverine sediments are highly polluted by heavy metals; therefore the evaluation of metal distribution in surface sediment is useful to assess pollution in the aquatic environment [3, 4]. Enriched Heavy metal concentrations (e.g. Cr, Ni, Cu, Mn, $\mathrm{Zn}, \mathrm{Ti}, \mathrm{Co}, \mathrm{Pb}, \mathrm{Cd}$ etc) in aquatic environment are often considered indicators of anthropogenic influence and are themselves of high potential risk to the natural environment. Therefore, it is important to assess and monitor the abundance of these heavy metals in aquatic ecosystems [5].

Evaluating the distribution and transfer of toxic metals between the sediment and water columns is of great importance. When heavy metals are introduced into the aquatic environment, they are redistributed throughout the water column. They may be deposited or accumulated in the sediments too [6]. Heavy metal concentration profiles in sediments can be used to identify the history and sources of pollution. The sources of major and minor elements in the aquatic sediment area may be the consequence of natural weathering, run-off from other water sources and atmospheric input or by anthropogenic impact. [7, 8].

The ever expanding city of Chennai offloads a million liters of sewage, which carries a wide variety of pollutants everyday into the river to the adjoining sea. The information on the riverine hydrograph of Chennai River is essential in the context of riverine pollution and consequent productivity of the environment. The present study was therefore undertaken with a view to provide much needed information on the heavy metal distribution in the sediments of Kortalaiyar River flowing into Chennai and its relation to the prevailing environmental conditions.

\subsection{Study Area}

\section{Materials And Methods}

Kortalaiyar River is one of the three rivers that flow in the Chennai metropolitan area.The river has a length of $136 \mathrm{Km}$ and it originates near Kaveripakkam in Vellore district and finally drains into the Bay of Bengal. The main Kortalaiyar River flows into Poondi reservoir. The water flows through Thiruvallur district from the Poondi reservoir, enters into the Chennai metropolitan area, and joins the sea at Ennore creek. Whenever the flood gates of Poondi reservoir are opened, a considerable volume of water drains into the sea 
through Kortalaiyar River near the Ennore Creek. The area for present study is 30 sampling points starting from Poondi reservoir to Ennore creek.

\subsection{Sediment Sampling And Analysis}

Thirty samples of surface sediments were collected in a air dried Zip Lock covers for two seasons, PreMonsoon (PRM) and Post-Monsoon (POM).The sampling points are given in Table-1

\begin{tabular}{|c|c|c|}
\hline Sample no & Latitude & Longitude \\
\hline 1 & $13^{\circ} 8^{\prime} 51.48^{\circ} \mathrm{N}$ & $79^{\circ} 48 ' 57.45$ 'E \\
\hline 2 & $13^{\circ} 9{ }^{\prime} 22.25 " \mathrm{~N}$ & $79^{\circ} 48 ' 43.12 \prime \mathrm{E}$ \\
\hline 3 & $13^{\circ} 12^{\prime} 41.03^{\prime \prime} \mathrm{N}$ & $79^{\circ} 52 ' 10.18$ 'E \\
\hline 4 & $13^{\circ} 13^{\prime} 43.57^{\prime \prime} \mathrm{N}$ & $79^{\circ} 53 ' 37.50$ "E \\
\hline 5 & $13^{\circ} 13^{\prime} 10.12^{\prime \prime} \mathrm{N}$ & $79^{\circ} 54^{\prime} 4.76$ "E \\
\hline 6 & $13^{\circ} 13^{\prime} 19.60^{\prime \prime} \mathrm{N}$ & $79^{\circ} 59^{\prime} 20.25$ 'E \\
\hline 7 & $13^{\circ} 13^{\prime} 38.80^{\prime \prime} \mathrm{N}$ & 7959'55.53'E \\
\hline 8 & $13^{\circ} 13^{\prime} 52.26^{\prime \prime} \mathrm{N}$ & $80^{\circ} 1{ }^{\prime 25.48}$ 'E \\
\hline 9 & $13^{\circ} 13^{\prime} 43.19^{\prime \prime} \mathrm{N}$ & $80^{\circ} 2{ }^{\prime} 27.78^{\prime \prime} E$ \\
\hline 10 & $13^{\circ} 14^{\prime} 26.66^{\prime \prime} \mathrm{N}$ & $80^{\circ} 2 ' 56.35^{\prime \prime} E$ \\
\hline 11 & $13^{\circ} 13^{\prime} 34.13^{\prime \prime} \mathrm{N}$ & $80^{\circ} 5^{\prime} 36.66^{\prime \prime} E$ \\
\hline 12 & $13^{\circ} 14^{\prime} 0.15^{\prime \prime} \mathrm{N}$ & $80^{\circ} 6{ }^{\prime} 23.22^{\prime \prime} \mathrm{E}$ \\
\hline 13 & $13^{\circ} 13$ '57.32' $\mathrm{N}$ & $80^{\circ} 6{ }^{\prime} 46.44^{\prime \prime} \mathrm{E}$ \\
\hline 14 & $13^{\circ} 14^{\prime} 6.64^{\prime \prime} \mathrm{N}$ & $80^{\circ}$ 6'55.76"'E \\
\hline 15 & $13^{\circ} 15^{\prime} 28.20^{\prime \prime} \mathrm{N}$ & $80^{\circ} 9^{\prime} 11.72^{\prime \prime} E$ \\
\hline 16 & $13^{\circ} 15^{\prime} 40.29^{\prime \prime} \mathrm{N}$ & $80^{\circ} 8$ '1.61'E \\
\hline 17 & $13^{\circ} 15^{\prime} 25.47^{\prime \prime} \mathrm{N}$ & $80^{\circ}$ 7'50.35"'E \\
\hline 18 & $13^{\circ} 15^{\prime} 12.38 \prime \mathrm{N}$ & $80^{\circ}$ 7'55.47'E \\
\hline 19 & $13^{\circ} 15^{\prime} 28.67^{\prime \prime} \mathrm{N}$ & $80^{\circ}$ 9'38.11"E \\
\hline 20 & $13^{\circ} 16^{\prime} 46.86^{\prime \prime} \mathrm{N}$ & $80^{\circ} 12 ' 43.41$ 'E \\
\hline 21 & $13^{\circ} 16^{\prime} 26.68^{\prime \prime} \mathrm{N}$ & 80¹3'39.99'E \\
\hline 22 & $13^{\circ} 16^{\prime} 22.20^{\prime \prime} \mathrm{N}$ & $80^{\circ} 13 ' 55.97 " E$ \\
\hline 23 & $13^{\circ} 16^{\prime} 25.92^{\prime \prime} \mathrm{N}$ & $80^{\circ} 14 ' 12.05$ "E \\
\hline 24 & $13^{\circ} 15^{\prime} 46.41^{\prime \prime} \mathrm{N}$ & $80^{\circ} 15 ' 10.06 "$ E \\
\hline 25 & $13^{\circ} 14^{\prime} 31.42^{\prime \prime} \mathrm{N}$ & $80^{\circ} 16^{\prime} 6.00 " E$ \\
\hline 26 & $13^{\circ} 13^{\prime} 0.81^{\prime \prime} \mathrm{N}$ & $80^{\circ} 16 ' 20.64^{\prime \prime} \mathrm{E}$ \\
\hline 27 & $13^{\circ} 12^{\prime} 36.68^{\prime \prime} \mathrm{N}$ & $80^{\circ} 16^{\prime} 55.03$ 'E \\
\hline 28 & $13^{\circ} 12^{\prime} 35.24^{\prime \prime} \mathrm{N}$ & $80^{\circ} 16 ' 55.85$ 'E \\
\hline 29 & $13^{\circ} 12^{\prime} 24.75^{\prime \prime} \mathrm{N}$ & $80^{\circ} 16^{\prime} 51.09$ "E \\
\hline 30 & $13^{\circ} 13^{\prime} 53.72^{\prime \prime} \mathrm{N}$ & $80^{\circ} 19^{\prime} 44.59$ 'E \\
\hline
\end{tabular}

Table-1 The latitude and Longitude of the Sampling Locations

The sediment samples were air dried at room temperature and then finely powdered using a Porcelain mortar and Pestle.It was sieved for further analysis.The heavy metals in the samples were analyzed.

\section{Results And Discussions}

The sediment samples were analyzed to find the presence of heavy metals namely Chromium, Nickel, Copper, Manganese, Iron, Zinc, Titanium, Cobalt, Lead and Cadmium. The concentration of these metals (except Iron) in the Pre Monsoon (PRM) and Post Monsoon (POM) are shown in Figure 1 and 2 respectively.

Iron is present in a very high concentration of $5491 \mathrm{mg} / \mathrm{kg}-9873.6 \mathrm{mg} / \mathrm{kg}$ in PRM and $2909.9 \mathrm{mg} / \mathrm{kg}$ $9623 \mathrm{mg} / \mathrm{kg}$ in POM .Most of the trace metals are closely associated with $\mathrm{Fe}$ and they clearly reflect the distribution pattern with the local redox conditions [9].

The concentration of $\mathrm{Fe}$ is maximum in sampling location 27 (both in the PRM and POM), which is towards Ennore creek from Manali.The strong reducing conditions in the Ennore Creek region favor sequestering of trace metals along with $\mathrm{Fe}$ in the surface layers [10]. 


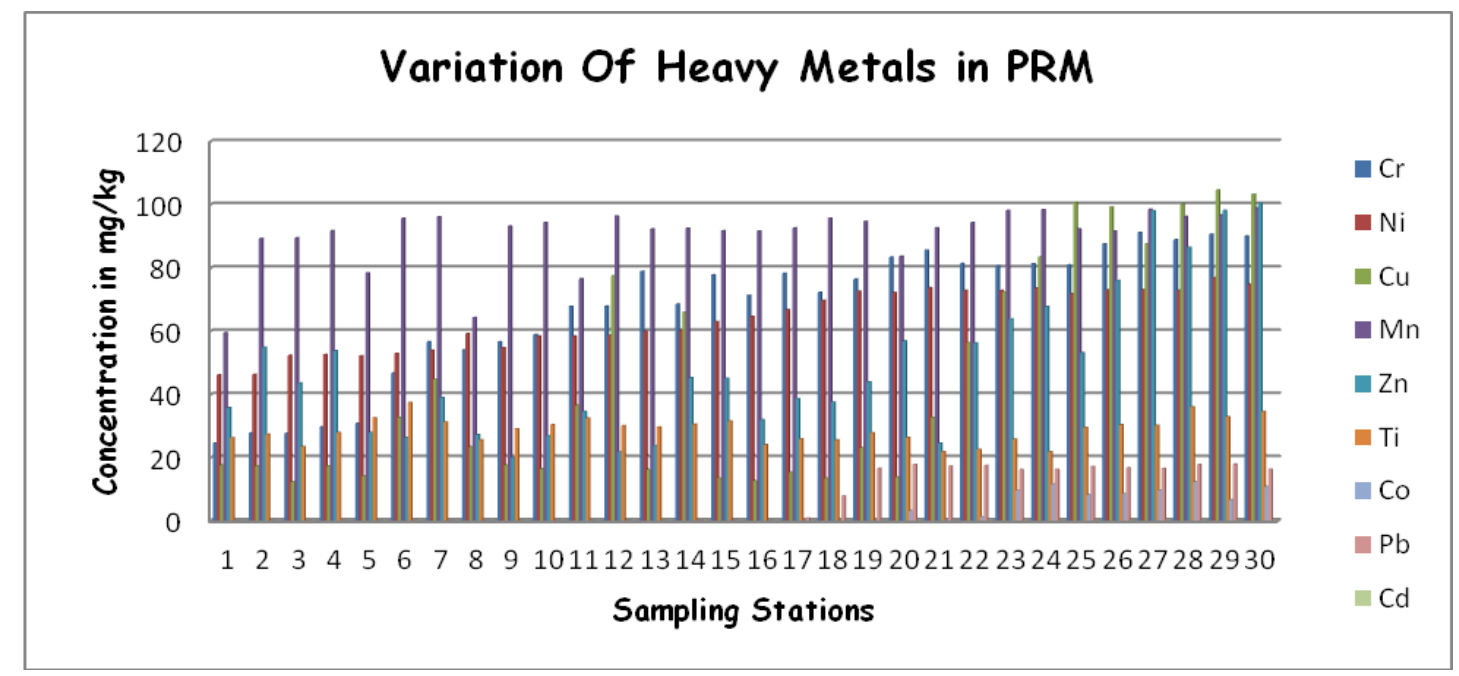

Fig 1

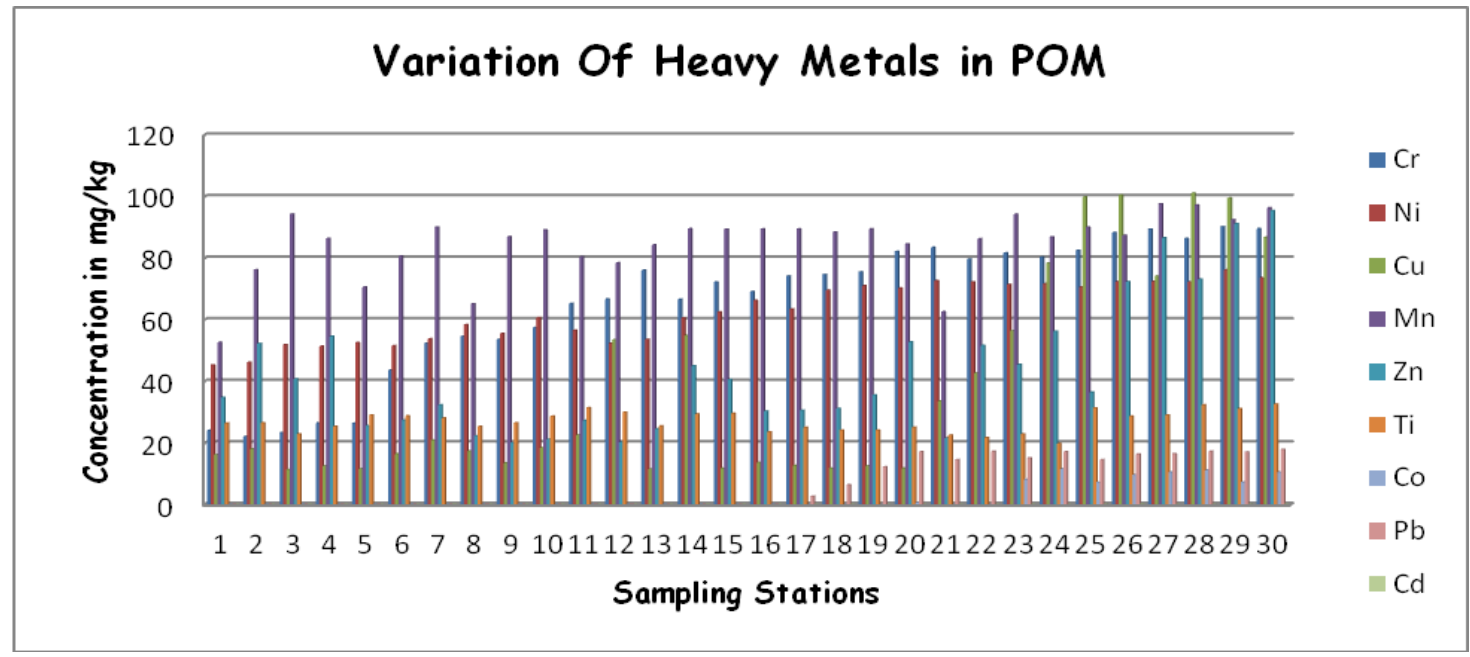

Fig 2

Chromium ranges from $24.6 \mathrm{mg} / \mathrm{kg}-91.2 \mathrm{mg} / \mathrm{kg}$ in PRM and $22.1 \mathrm{mg} / \mathrm{kg}-90.2 \mathrm{mg} / \mathrm{kg}$ in POM . The observed $\mathrm{Cr}$ concentration is very high due to lithogenic sources, industrial wastages and anthropogenic activities. $\mathrm{Cr}$ is usually found naturally in rocks, soil, plants, and animals, including human beings [11].

It can also be present in combined form with other elements as chromium salts. Some of these salts are soluble in water. $\mathrm{Cr}$ rarely exists naturally in pure metallic form. Chromium does not degrade and can not be destroyed.It goes on accumulating in due course of time. It is an important element in metallurgy, and is used as a constituent of stainless steel and in "Chrome plating" and as pigments. The high concentration of $\mathrm{Cr}$ is mainly attributed to the industrial effluents and it is also associated with organic particles.[12]

Nickel was analyzed to be present in the concentration of $46.2 \mathrm{mg} / \mathrm{kg}-76.9 \mathrm{mg} / \mathrm{kg}$ in PRM and 45.3 $\mathrm{mg} / \mathrm{kg}-76.2 \mathrm{mg} / \mathrm{kg}$ in POM. Nickel is suspected to be an essential trace elements for plants as well as for animals and used principally in its metallic form combined with other metals and nonmetals as alloys [13] Metals such as chromium, copper, and nickel have interacted with organic matter in aqueous phase and settled to the bottom, resulting in a high concentration of these metals in the sediment [14]. The higher amount of nickel concentration is due to lithogenic sources, industrial wastages and sometimes-anthropogenic activities. Nickel is a fairly toxic element but the volatile compounds of $\mathrm{Ni}$ are highly poisonous.

Copper exists from $12.3 \mathrm{mg} / \mathrm{kg}$ to $104.6 \mathrm{mg} / \mathrm{kg}$ in PRM and $11.4 \mathrm{mg} / \mathrm{kg}-101.1 \mathrm{mg} / \mathrm{kg}$ in POM. Major anthropogenic sources of $\mathrm{Cu}$ include agrochemicals (fertilizers and pesticides), wood preservatives, electroplating,and antifouling paints [15] During the monsoon period, when freshwater discharge is maximum, the copper level was high and dissolved labile copper concentrations were also high both at the surface and in bottom waters[16] . 
Occurrence of higher concentration of $\mathrm{Cu}$ in the water can also be attributed to the result of natural weathering of soil and discharges from industries and sewage-treatment plants [17]

Manganese has the concentration values of $59.6 \mathrm{mg} / \mathrm{kg}-99.1 \mathrm{mg} / \mathrm{kg}$ in PRM and $52.7 \mathrm{mg} / \mathrm{kg}-97.3$ $\mathrm{mg} / \mathrm{kg}$ in POM. It is predicted that fertilizer runoff is one of the predominant manmade sources of Mn enrichment in the riverine environment [18].

Zinc is present in high concentrations of $20 \mathrm{mg} / \mathrm{kg}-100.4 \mathrm{mg} / \mathrm{kg}$ in PRM and $20.3 \mathrm{mg} / \mathrm{kg}-95.4 \mathrm{mg} / \mathrm{kg}$ in POM. the higher concentration of Zinc in sediment may be attributed to the presence of unused remains of Zinc sulphate in fertilizers [19].

Maximum concentration of $\mathrm{Zn}$ in sediments nearby Ennore is probably due to the discharges of effluents from the petrochemical, painting industries [20]. Zinc can enter the aquatic environment from anumber of sources, including industrial discharges, sewage ,effluent and runoff [21] .Zinc is present not only in rock and soil, but also in air, water and the biosphere. Plants, animals and human beings contain zinc, and this metal is used for anti corrosion coatings, roof cladding,batteries and some specialized alloys.

Titanium ranges from $21.9 \mathrm{mg} / \mathrm{kg}-37.4 \mathrm{mg} / \mathrm{kg}$ in PRM and $19.8 \mathrm{mg} / \mathrm{kg}-32.4 \mathrm{mg} / \mathrm{kg}$ in POM. There is no evidence to suggest that Ti performs any necessary role in the human body [22] Titanium is considered to be non-toxic, because of its poor absorption and retention in living organisms [23]. Potential anthropogenic sources of $\mathrm{Ti}$ in the environment include paint pigments ( $\mathrm{TiO}_{2}$ pigment accounts for the largest use of the element) and its alloys with $\mathrm{Al}, \mathrm{Mo}, \mathrm{Mn}$ and $\mathrm{Fe}$, which are used extensively in aircraft, ship and missile manufacture.

Metals such as chromium, copper, and nickel have interacted with organic matter in aqueous phase and settled to the bottom, resulting in a high concentration of these metals in the sediment [14]

Cobalt, Lead and Cadmium has a concentration below detectable level in the sampling locations from the Poondi reservoir to the city belt.They show a maximum concentration of $12.3 \mathrm{mg} / \mathrm{kg}, 17.9 \mathrm{mg} / \mathrm{kg}, 0.154$ $\mathrm{mg} / \mathrm{kg}$ respectively in PRM and $11.6 \mathrm{mg} / \mathrm{kg}, 17.9 \mathrm{mg} / \mathrm{kg}, 0.135 \mathrm{mg} / \mathrm{kg}$ respectively in POM. The lower values of lead might be attributed to less solubility of $\mathrm{Pb}$ containing minerals in natural water [24, 25]. The high concentrations of the metals during pre monsoon season mainly due to the heavy input of untreated industrial effluents from Ennore area .Cadmium is one of the most dangerous pollutants due to its high potential toxic effects.The primary use of water high in $\mathrm{Cd}$ could cause adverse health effect to consumers such as renal disease and cancer [26]. The presence of $\mathrm{Cd}$ in the sediments is attributed to the reasons of human activities such as discharge of industrial effluents of fertilizers industries and chemical industries along the river. The probable sources of $\mathrm{Cd}$ in the river water are from the catchment soils and runoffs from agricultural soils.

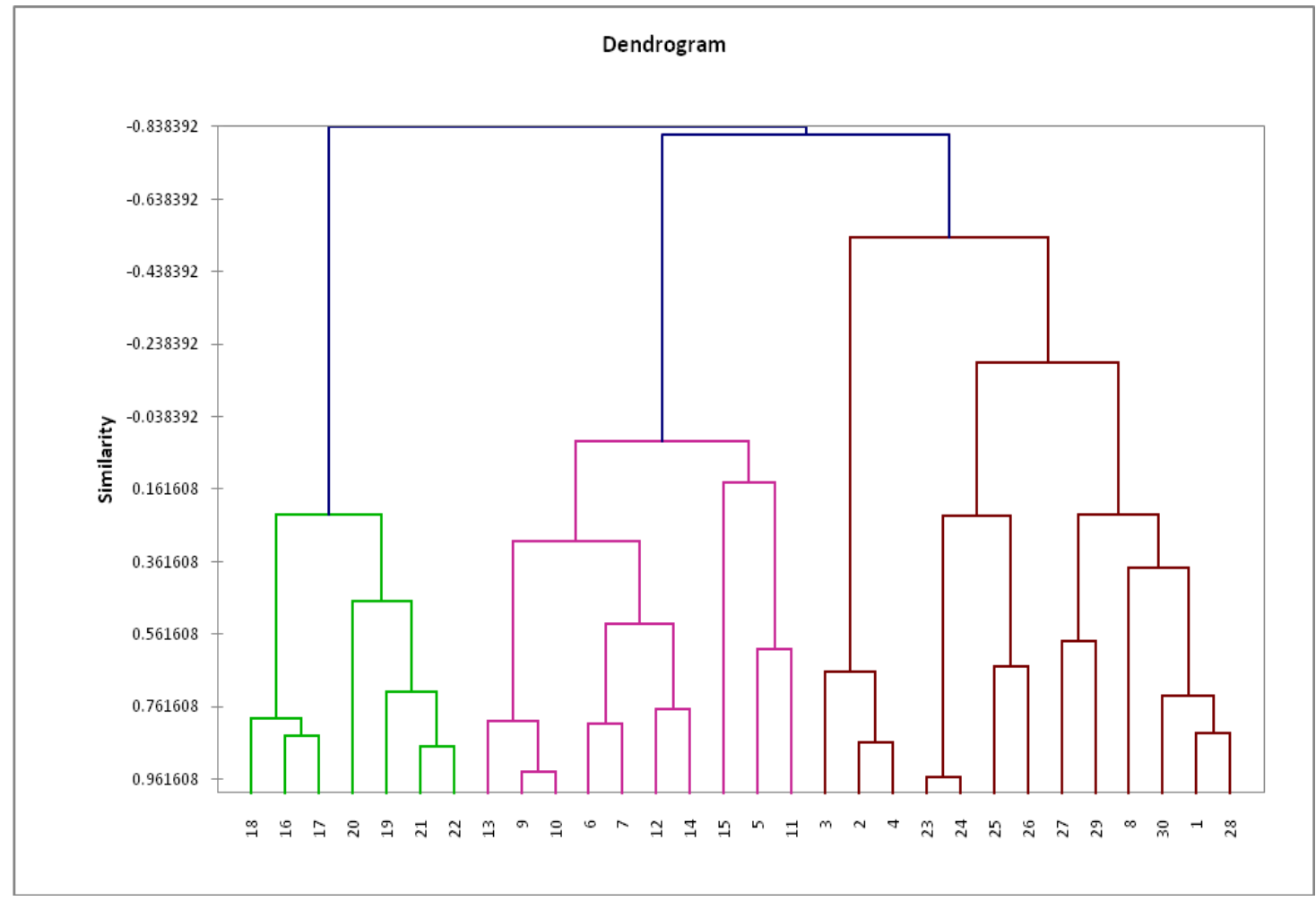

Figure-3 Dendrogram for PRM 
In order to study the similarity between the sampling locations a dendrogram is constructed using agglometric hierarchial clustering. The similarity is evaluated using Pearson correlation coefficient and complete linkage agglomeration method. The dendrogram obtained for the PRM season is as shown in Fig. 3

Based on the dendrogram obtained,it is clear that the thirty sampling locations are clustered into three.The clustering is based on the availability and the concentration of the heavy metals in each sampling location There are 13 locations in the first cluster, 10 in the second cluster and 7 in the third cluster.Table -2 gives the information regarding the three clusters obtained for PRM.

\begin{tabular}{|l|l|l|l|}
\hline S.No. & Class 1 & Class 2 & Class 3 \\
\hline 1 & 1 & 5 & 16 \\
\hline 2 & 2 & 6 & 17 \\
\hline 3 & 3 & 7 & 18 \\
\hline 4 & 4 & 9 & 19 \\
\hline 5 & 8 & 10 & 20 \\
\hline 6 & 23 & 11 & 21 \\
\hline 7 & 24 & 12 & 22 \\
\hline 8 & 25 & 13 & \\
\hline 9 & 26 & 14 & \\
\hline 10 & 27 & 15 & \\
\hline 11 & 28 & & \\
\hline 12 & 29 & & \\
\hline 13 & 30 & & \\
\hline
\end{tabular}

Table-2: Clusters obtained for PRM

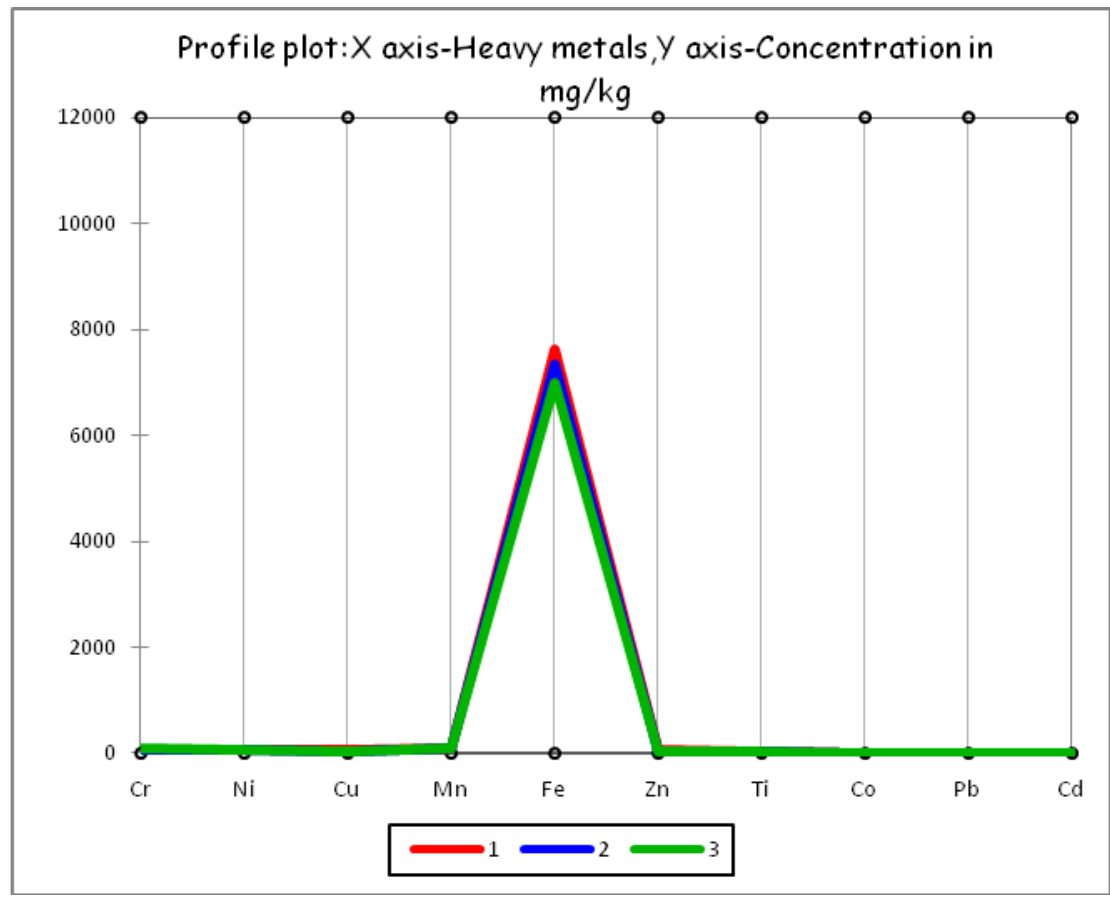

Figure- 4 Profile plot for PRM

The profile plot obtained for the clusters are given in Fig.4.It is evident from the profile plot that Fe has the maximum concentration in all the sampling locations making it a major metal.The sampling locations in class I of the clusters show maximum concentration of cadmium in sampling location 26, Iron and Chromium in sampling location 27,Lead,Copper and Nickel in sampling location 29, Cobalt in sampling location 28, Manganese and Zinc in sampling location 30.The minimum concentration of Chromium ,Manganese and Nickel is present in sampling location 1,Copper in sampling location 3 and Titanium in sampling location 24.

Class II explains the maximum concentration of Titanium alone in sampling location 6.The minimum concentration is that of Zinc in sampling location 9. This explains the moderate concentrations of the heavy metals in Class II.

In class III, none of the heavy metals show the maximum concentration but sampling location 21 attributes to the minimum concentration of Iron and Titanium. This depicts the availability of the heavy metals in low concentration. Therefore, Class I, II and III clusters can be identified as highly concentrated, moderately concentrated and slightly concentrated locations with regard to heavy metals. 
The dendrogram for the POM season is as shown in Fig.5.Similar to PRM season; three clusters are obtained for POM season too. In this cluster analysis the first cluster contains 8 locations, second contains 14 and the third contains 8 locations.

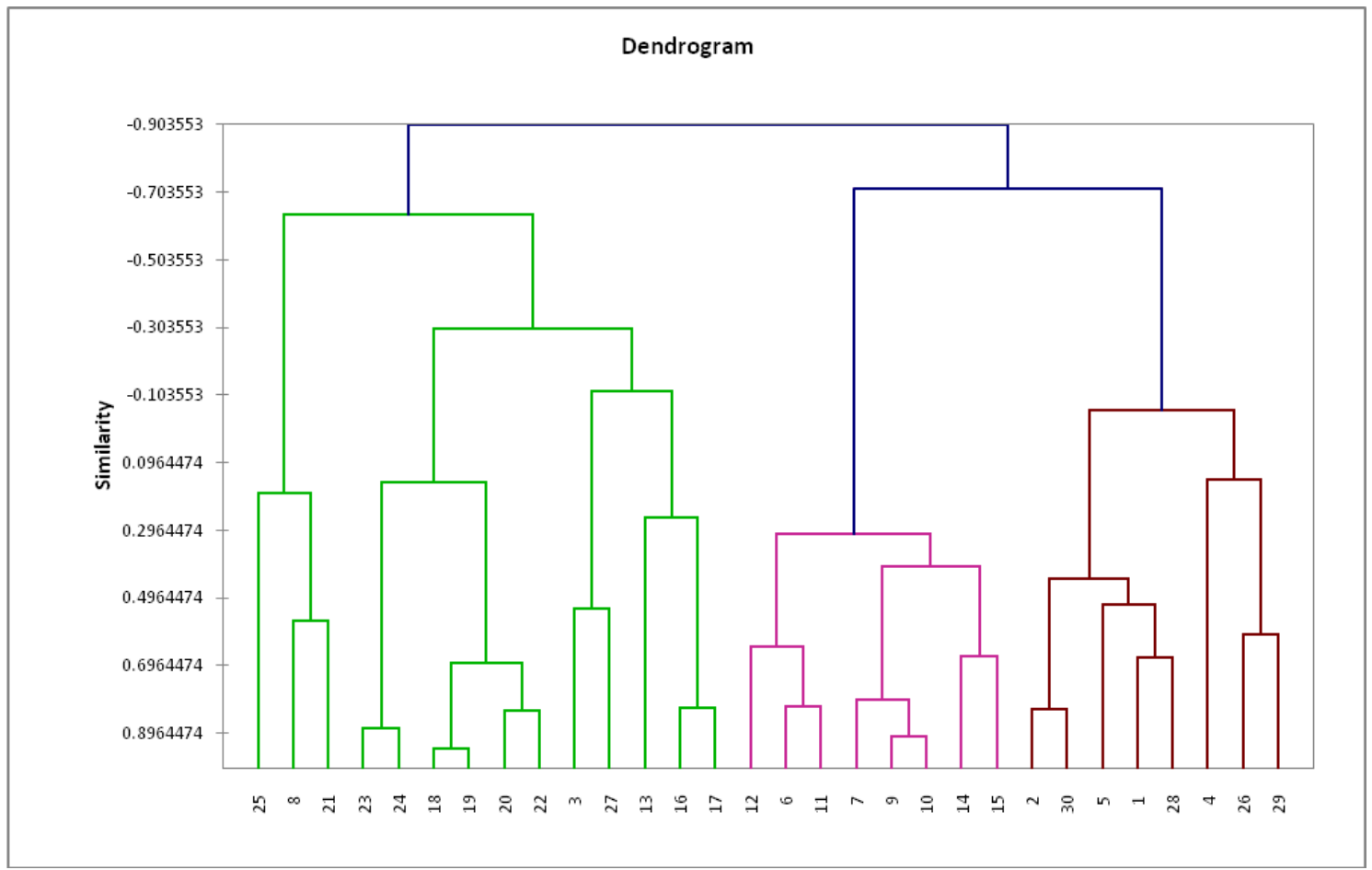

Figure-5 Dendrogram for POM

The sampling locations are clustered into three classes as given in Table-2.The clusters of sampling locations obtained attributes to the similarity in the distribution of the heavy metals.

\begin{tabular}{|l|l|l|l|}
\hline S.No. & Class 1 & Class 2 & Class3 \\
\hline 1 & 1 & 3 & 6 \\
\hline 2 & 2 & 8 & 7 \\
\hline 3 & 4 & 13 & 9 \\
\hline 4 & 5 & 16 & 10 \\
\hline 5 & 26 & 17 & 11 \\
\hline 6 & 28 & 18 & 12 \\
\hline 7 & 29 & 19 & 14 \\
\hline 8 & 30 & 20 & 15 \\
\hline 9 & & 21 & \\
\hline 10 & & 22 & \\
\hline 11 & & 23 & \\
\hline 12 & & 24 & \\
\hline 13 & & 25 & \\
\hline 14 & & 27 & \\
\hline
\end{tabular}

Table-2 Clusters obtained for POM

The profile plot obtained for the clusters in the POM season is as shown in Fig. 6. 


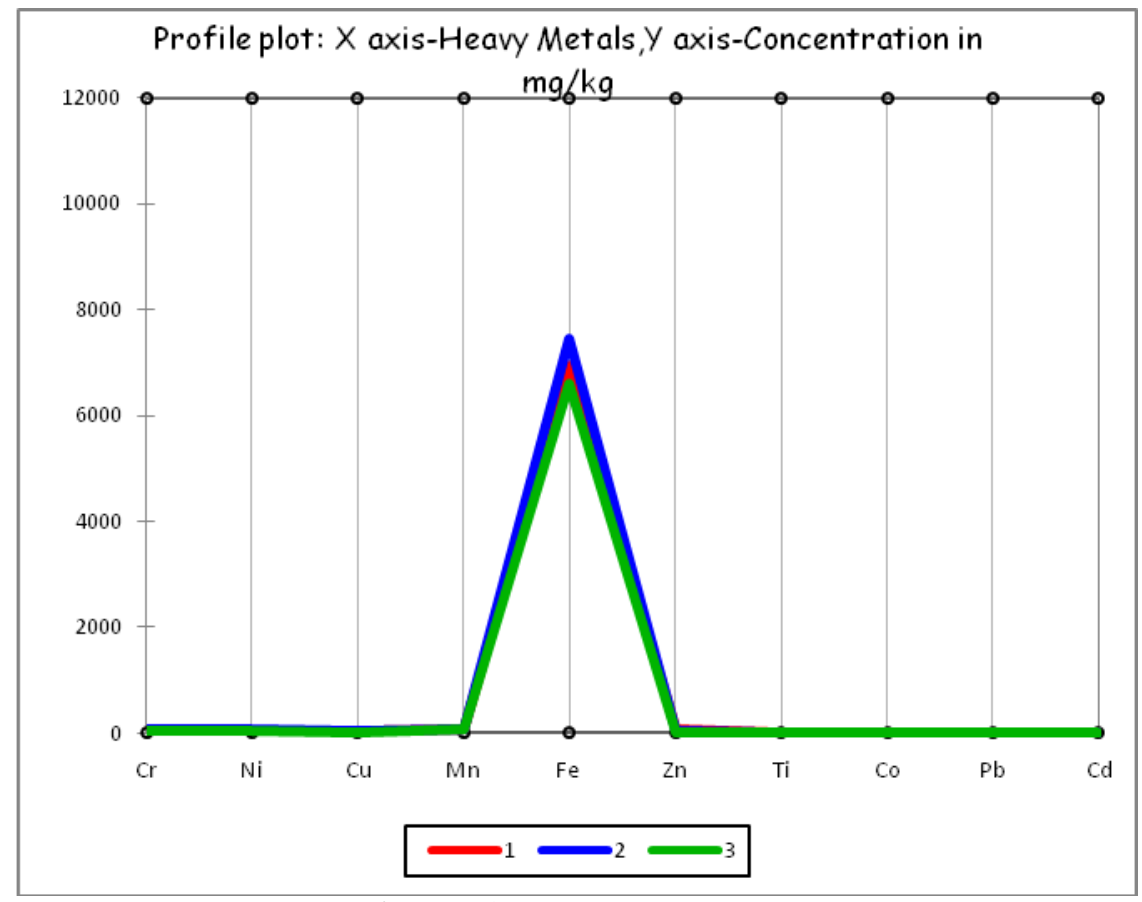

Figure- 6 Profile Plot for POM

The profile plot shows the maximum concentration of $\mathrm{Fe}$ in all the three clusters. Cluster 2 is found to have the maximum concentration of $\mathrm{Fe}$ followed by cluster 1 and 3respectively. The concentration of other metals vary in a continuous manner. The anomalous concentration of $\mathrm{Fe}$ in the samples makes $\mathrm{Fe}$ a major metal more than a heavy metal. The difference of clustering in POM and PRM seasons is due to the seasonal distribution and is also due to the excess input of the industrial effluents washout from the upstream side of supply channels that feed the river, which is sluggish in flow during the PRM season.

Based on the three classes obtained for POM, it can be inferred that equal number of sampling locations fall under Class I and Class III .Class I contains eight sampling locations. Cadmium is present in its maximum concentration in sampling location 26. The presence of maximum concentration of Copper is depicted in sampling location 28.Chromium and Nickel in the sampling location 29 is marked to have the maximum concentration. There is good correlation between the Zinc, Titanium and Lead as they show their maximum concentration in the sampling location 30.The minimum concentration of Iron andChromium is in sampling locations 4 and 2 respectively.Nickel and Manganese are slightly available in the sampling location 1 .

Class II contains 14 sampling locations. .But the availability of the heavy metals is not appreciated compared to class I. Iron and Manganese are present in higher concentrations in sampling location 27 and Co records its maximum concentration in sampling location 24. The minimum concentration of Copper and Titanium is analyzed to be present in sampling locations 3 and 24 respectively.

Class III contains eight sampling locations which has none of the heavy metals in maximum concentration but has a minimum concentration of $\mathrm{Zn}$ in sampling location 12.There is a significant difference in the distribution pattern of heavy metals in PRM and POM. This difference is associated with the rainfall in the city.

The elements with different chemical properties may appear with similar distribution patterns in the sediments due to the fact that they are linked to the same carrier particle with similar sedimentological properties. The type of carrier particle and the way in which elements are bound to it determine the element's geochemical fraction in sediments [26, 27].

Chemical leaching methods using acetic acid [28], weak $\mathrm{HCl}$ solutions [29, 30] and sequential extractions can be used in the partition of total metal concentrations. In addition, acid-leachable techniques can also be used successfully to estimate the level of enrichments in trace metals in industrialized areas.

\section{Conclusion}

The geochemical cycle of trace metals in the riverine region is an important process to determine the present level of metal enrichment which interacts with the estuaries and other effluent input. The heavy metals play a major role in the ecotoxicology of the river ecosystem. 
The significance of anthropogenic metal enrichment and environmental effects in the Kortalaiyar river sediments could be assessed through this study. Hence a regular monitoring of the point sources is suggested to minimise the effects of pollution in the near environments of the river.

\section{References}

[1]. I.R Santos, E.V Silva-Filho, C.E Schaefer, M.R Albuquerque-Filho, Campos LS. Heavy metal contamination in Coastal sediments and soil near the Brazilian Antartic Station, King George Island. Marine Poll. Bulletin 50, 2005, 185-194.

[2]. Anna Nikulina, Wolf-Christian Dullo. Eutrophication and heavy metal pollution in the Flensburg Fjord: A reassessment after 30 years. Marine Poll. Bulletin 58, 2009, 905-915.

[3]. V Cuculic, N Cukrov, Kwokal Z Mlakar. Natural and anthropogenic sources of $\mathrm{Hg}, \mathrm{Cd}, \mathrm{Pb}, \mathrm{Cu}$ and $\mathrm{Zn}$ in water and sediment of Mljet park, Croatia. Estu. Coastal and Shelf Sci. 81(3), 2009, 311-320.

[4]. M.I Abubakr. Combining multivariate analysis and geochemical approaches for assessing heavy metal level in sediment from Sudanese harbour along the Red Sea coast. Microchem J. 90(2), 2008, 159-163.

[5]. Vlado Cuculic, Neven Cukrov, Z eljko Kwokal, Marina Mlakar. Natural and anthropogenic sources of $\mathrm{Hg}, \mathrm{Cd}, \mathrm{Pb}, \mathrm{Cu}$ and $\mathrm{Zn}$ in seawater and sediment of Mljet National Park, Croatia. Estu., Coastal and Shelf Sci. 81, 2009, 311-320.

[6]. C Christophoridis, D Dedepsidis, K Fytianos. Occurrence and distributed of selected heavy metals in the surface sediments of Thermaikos Gulf, N.Greece. Assessment using pollution indicators. J. Hazardous Mat 168, 2009, 1082-1091.

[7]. H Zhang W Feng, J Chang, J Qu, H Xie, L Yu. Heavy metal concentration in surface sediments of Yangtze River intertidal zone: An assessment from different indexes. Environ. Pollut .157, 2009, 1533-1543.

[8]. M.G Yalcin, I Narin, M Soylak. Multivariate analysis of heavy metal contents of sediments from Gumusler creek, Nigde, Turkey. Environ.Geol. 54(9), 2008, 1155-1163.

[9]. M Jayaprakash, MP Jonathan, S Srinivasalu, S Muthuraj, V Ram-Mohan, N Rajeshwara-Rao. Acid-leachable trace metals in sediments from an industrialized region (Ennore Creek) of Chennai city, SE coast of India: an approach towards regular monitoring. Estu., Coastal and Shelf Science 76, 2008, 692-703.

[10]. K.W.G LeBlanc, R.A Fitzgerald, G.V Winters, D.E Buckley, R.E Cranston. Geochemical data from analysis of sediments and pore waters obtained from cores collected in Halifax inlet. Geol. survey of Canada open file report 1991, 2345

[11]. A Chandrasekaran, M.V Mukesh, P Anantharaman, M Tamilselvi, R Muthukumarasamy, T Manivel, R Rajmohan, Trace Metal Concentration in Sediments ofTamirabarani River in Relationships with Physico Chemical Characteristics - A Study Using Gis Application. Intl. J. of Innov. Tech. and Expl Engg. 3(2),2013, 2278-3075.

[12]. U Forstner, W Calmano, J Schoer,. Heavy metals in bottom sediments and suspended material from the Elbe, Weser and Ems estuaries and from the German Bight. Thalassia jugsol 28, 1982, 97-122

[13]. S. J Aboud \& N Nandini, Heavy Metal Analysis and Sediment Quality values in Urban Lakes, Amer. J. of Environ. Sci., 5(6), 2009, 678-687.

[14]. Abida Begum, M Ramaiah, Harikrishna, I Khan, \& K Veena. Heavy Metal Pollution and Chemical Profile of Cauvery River Water, E- J. of Chem. 6 (1), 2009, 47-52.

[15]. L.J Schuler, T.C Hoang, G.M Rand .Aquatic risk assessment of copper in freshwater and saltwater ecosystems of South Florida. Ecotoxic.17, 2008, 642-659.

[16]. M.D George, K Sawkar, C.V.G Reddy. Determination of $\mathrm{Cd}, \mathrm{Pb}$ and $\mathrm{Cu}$ in Mandovi Estuary by Differential Pulse Anodic Stripping Voltammeter. Ind. J. of Marine Sci.3, 1984, 64-68.

[17]. J. Hutchinson. on some examples of arsenic-keratosis of the skin and of arsenic-cancer. Trans. Pathol. Soc. London, 39, 1988, 352393

[18]. E.C Wolters, C.C Huang, C Clark. Positron emission tomography in manganese intoxication. Ann Neurol 26, 1989, 647-651

[19]. R Reza and G Singh, Heavy metal contamination and its indexing approach for river water, Int. J. of Environ. Sci. and Tech. 7(4), 2010, 785-792.

[20]. Y.P Lin, T.P Teng, T.K Chang .Multivariate analysis of soil heavy metal pollution and land scape pattern in Changhua County in Taiwan. Landsc Urban Plan 62, 2002, 19-35

[21]. A.B.A Boxall , S.D Comber, A.U Conrad, J Howcroft, N Zaman .Inputs, Monitoring and Fate Modelling Of Antifouling Biocides in UK Estuaries. Marine Poll. Bulletin 40, 2000, 898-905

[22]. W Mertz. Trace elements in human and animal nutrition. New York: Academic Press, 1987, 347-371.

[23]. T Venugopal, L Giridharan, and M Jayaprakash. Characterization and risk assessment studies of bed Sediments of River Adyar- An application of speciation study, Intl. j. of Environ. Research, 3(4), 2009, 581-598.

[24]. O.S Fatoki, N Lujiza \& A.O Ogunfowokon. Trace metal pollution in Umtata River, Water SA. Pretoria 28(2).2002. 183-189

[25]. E.A Passos, C Jeferson Alves, S Izaias dos Santos, H Patrocínio Alves, Carlos B Alexandre, Garcia, Antonio, \& C Spinola Costa. Assessment of trace metals contamination in estuarine Sediments using a sequential extraction technique and principal component analysis. Micro Chem. 96, 2010, 50-57.

[26]. W Salomons, U Fo"rstner. Trace metal Analysis on Polluted Sediments, Environ. Tech. Letters, Vol.1, 1980, 506

[27]. L Hakanson, M Jansson. Principles of Lake Sedimentology. Springer, Berlin, 1983, 316

[28]. D.H Loring .Geochem. Of Zinc, Copper and lead in the sediments of the estuary and Gulf of St. Lawerence. Canadian J. of Earth Sci. $15,1978,757-772$.

[29]. S.N Luoma, E.A Jenne. Estimating Bioavailability of sediment bound trace metals with chemical Extractants .In; Hemphill, D.d.(Ed.),Trace substances in Environment health .Univ. Missouri press ,Columbia, MO, 1976,343-351.

[30]. P Szefer, G.P Glasby, A Kusak. K Szefer, H Jankowska, M Wolowicz, A.A Ali. Evaluation of anthropogenic flux of metallic pollutants into Puck Bay, Southern Baltic. App. Geochem. 13, 1998, 293-304. 